\title{
Delivery of functionalized nanoformulations for small interfering RNA (siRNA): recent innovative strategies
}

\begin{abstract}
siRNA is a new hope for treating unanswered diseases. A large number of researches on small or larger scale are going on in the research world to find its possibilities of positives and negatives A plethora of research a small or larger scale is going on in the research world to find the possibilities of positives and negatives. There are some problems in siRNA to be effective in in vivo systems ever though effective in in vitro systems. Those problems have been potentially solved by using nanocarriers and its targeting to the site of action; making the other cells devoid of its off targeting and/or immunogenicity. Here in this brief review, we have given basic information Here in this brief review, we have given brief basic information, discussed challenges of siRNA delivery and important strategies along with representative compilation of some recent strategies, giving the glimpse of level of innovative thinking for execution of a desired application/treating a specific diseased condition.
\end{abstract}

Keywords: siRNA, targeting delivery, functionalization, nanoparticles, nanostructures, silencing, Knockdown
Volume 3 Issue 2 - 2017

\author{
Sandeep Kumar,' Vinod Kumar Yata,' Isha \\ Dhamija, ${ }^{2}$ Shashank Garg' \\ 'Department of Biotechnology, National Institute of Technology, \\ India \\ ${ }^{2}$ Post Graduate Institute of Medical Sciences, India
}

Correspondence: Isha Dhamija, College of Pharmacy, Post Graduate Institute of Medical Sciences, Rohtak, Haryana, India (I2400I),Email ishaa25@gmail.com

Sandeep Kumar, Department of Biotechnology, Nationa Institute of Technology, Jalandhar, Punjab, India (I440I I), Email katariatniper@gmail.com

Received: January 31, 2017 | Published: April I2, 2017
Abbreviations: RISC, RNA-induced silencing complex; siRNAs, small interfering ribonucleic acids; MDR, multi drug resistance; dsRNA, double-stranded RNA; GALT, gut associated lymphatic tissue; RVG, rabies viral glycoprotein.

\section{Introduction}

Small interfering ribonucleic acids (siRNAs) or silencing RNAs, are ribose sugar based nucleic acid of 20-25 base pairs. siRNA act in the RNA interference (RNAi) pathway and degrade mRNA of complementary sequence thus interfere in translation. The mechanism involves dicing of siRNA by Dicer protein resulting in further small fragments. Among the further small fragments of siRNA, one is having affinity for RNA-induced Silencing Complex (RISC). RISC and dicer fragmented siRNA bound complex get attached as per nitrogenous base pair complementarity to translating messenger RNA (mRNA) leading to its degradation called gene silencing or post transcriptional silencing (Figure 1).

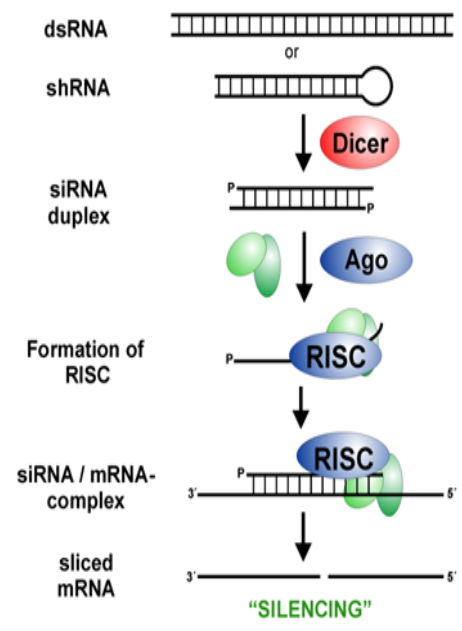

Figure I Mechanism of siRNA action.'
RNAi pathway using high specificity/efficiency siRNA can silence the expression of theoretically every gene. Since discovery of RNAi pathway, it has attracted great interest for treatment of diseases especially untreatable/undruggable like cancer, viral infection, genetic disorders and so on by introducing externally designed siRNA having complement sequence of the target gene or gene of interest. ${ }^{2}$ The condition called as multi drug resistance (MDR) gained by cancer cells or infecting organisms creates a big threat and challenge for health provider. Here as well, RNAi therapy can down regulate the key gene involved in creating the resistance. ${ }^{3}$ Triggers for RNAi pathway include foreign DNA or double-stranded RNA (dsRNA) of viral origin, aberrant transcripts from repetitive sequences in the genome such as transposons, and pre-microRNA (miRNA). ${ }^{1}$ siRNA has been advantageous than other antisense sequences (shRNA, miRNA) because single siRNA sequence has been shown to carry out many cycles of mRNA cleavage. ${ }^{4}$

\section{Discussion}

\section{Challenges to siRNA as therapeutics}

The delivery of siRNA as drug is a great challenge in therapeutics due to its inherent characteristics i.e. negative charge, large molecular weight, size, instability mainly due which leads to its degradation due to plasma \& intracellular endonucleases (RNAase) and ultimately lastly it should be recognized by and imbibed into RISC retaining its affinity for mRNA. ${ }^{3}$ The instability in plasma (half life: few minutes to an hour) is first and major issue in bringing this new hope to therapeutic level at the site of action or tissue expressing aberrant gene. Apart from its efficiency or bioavailability problems, siRNA therapy also faces off-targeting as a major drawback. Off-targeting means the silencing of other genes than the key/targeted/aberrant gene, which may lead to unexpected transformed cellular systems. This off-targeting can be kept aside by selecting the appropriate sequence against targeted mRNA. The sequence of selected siRNA, should not match with "seed region" of miRNA and finally be tested thoroughly for change in expression of normal proteins. Other 
unpredictable challenge is immunogenicity along with toxicity, which must be addressed in the way of siRNA drug development. ${ }^{5}$

In comparison to systemic delivery of siRNA, local delivery faces fewer barriers e.g. a study showed similar level of effect free siRNA and liposomal encapsulated siRNA when delivered intranasal to target respiratory virus. ${ }^{6,7}$ Intranasal delivery is not a solution to all the unsolvable or difficult to handle plethora of diseases which can be potentially treated by siRNA. So, targeting of siRNA specifically to tissues with conceptual strategies has been tried since the concept of siRNA has emerged.

Recently, nanocarriers are emerging and are explored to the maximum due to their unexpected positive properties favoring the delivery of larger biomolecules. ${ }^{8-10}$ Similarly, many studies have been conducted using nanocarriers in order to stabilized or safeguard of siRNA in systemic or oral delivery. Apart from stability, targeting delivery of siRNA is also a mandatory requirement for its development to bring the therapeutic level and reducing off-targeting problem.

\section{Targeting of siRNA to site of action: a solution to va- rious challenges}

The above mentioned problems of siRNA delivery haves been tried to resolve, since its initial year of its conception. A beautiful approach, to stabilize the siRNA in systemic delivery, to handle large sized molecule, to target by specific ligand binding and to reduce the possibility of immunogenicity was presented by Seow et al. They isolated endogenous nano-vesicles i.e. exosomes from dendritic cells, to encapsulate siRNA for its instability and immunogenicity issues. Exosomes are used by the cells to transport inherent/synthesized larger molecules. While targeting to brain was achieved by expressing the rabies viral glycoprotein (RVG)-peptide (neuron specific targeting peptide and binds with high affinity with acetylcholine receptor) \& a FLAG epitope (a signal peptide) and their fusion with normally expressed protein of exosomal membrane (Lamp2b) by genetic engineering concepts and protocols (Figure 2). Such a preparation of siRNA delivery showed $60 \%$ knockdown of target protein and $62 \%$ knockdown of target mRNA (BACE1 for Alzheimer's disease). ${ }^{11}$

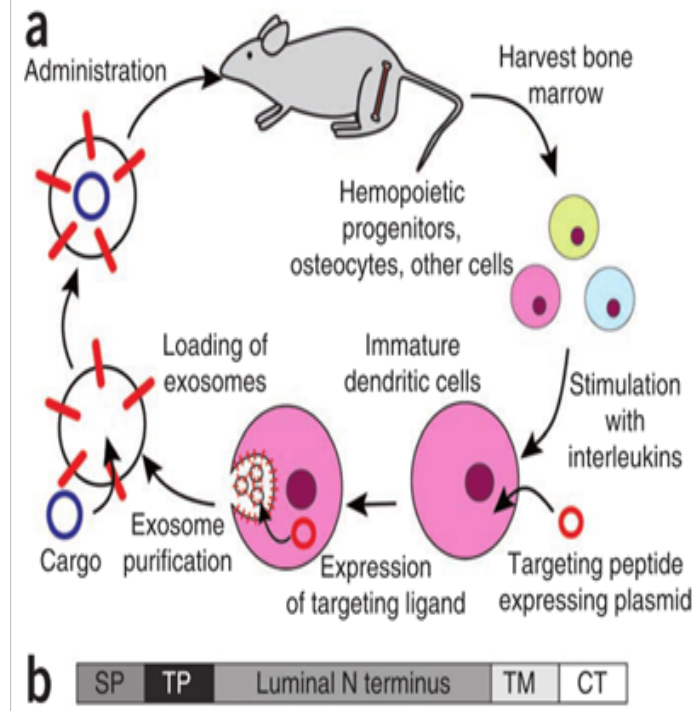

Figure 2 Step wise preparation of siRNA containing self produced exosomes with expressed genetically engineered targeting peptides (a) and gene transcript.Adapted from" with permission from "Nature Publisher".
Severe inflammatory responses have been associated with many diseases and treated as primary therapy to alleviate from painful conditions. Macrophages generate inflammatory responses and siRNA were designed to silence these causative genes or proteins. Moreover, for better patient compliance the strategies for oral delivery were also implemented. $\beta 1,3-\mathrm{D}$ glucan are hollow, porous and microsized particles; isolated from baker's yeast after removing cell wall and cytoplasm; having receptors (Dectin 1) receptor for $\beta$ 1,3-D glucan are found over M cells of intestinal Payer's patches for which helps in its internalization and its transfer to Gut Associated Lymphatic Tissue (GALT) which lies just beneath Payer's patches. Macrophages (containing glucan particle) from GALT are reported to move to other tissues as well transferring glucan particle to macrophages throughout the body. $\beta$ 1,3-D glucan were made fluorescent with fluorescein (green under confocal microscopy) for tracking purpose. First core tRNA was added in order to have a primary coat of polyethylene amine (PEI) (cationic polymer). Dy547-labelled siRNA (red under confocal microscopy), targeting the tumor necrosis factor $-\alpha$ through knockdown of mitogen activated protein kinase- 4 , was sandwiched between PEI layer as shown in Figure 3. In vitro results showed that 40 pico moles siRNA showed $70-80 \%$ knockdown of the mRNA of mitogen activated protein kinase- 4 while in vivo results showed $70 \%$ of mRNA knockdown at dose $20 \mathrm{mg} \mathrm{kg}^{-1}$ rat daily for eight days. ${ }^{12}$

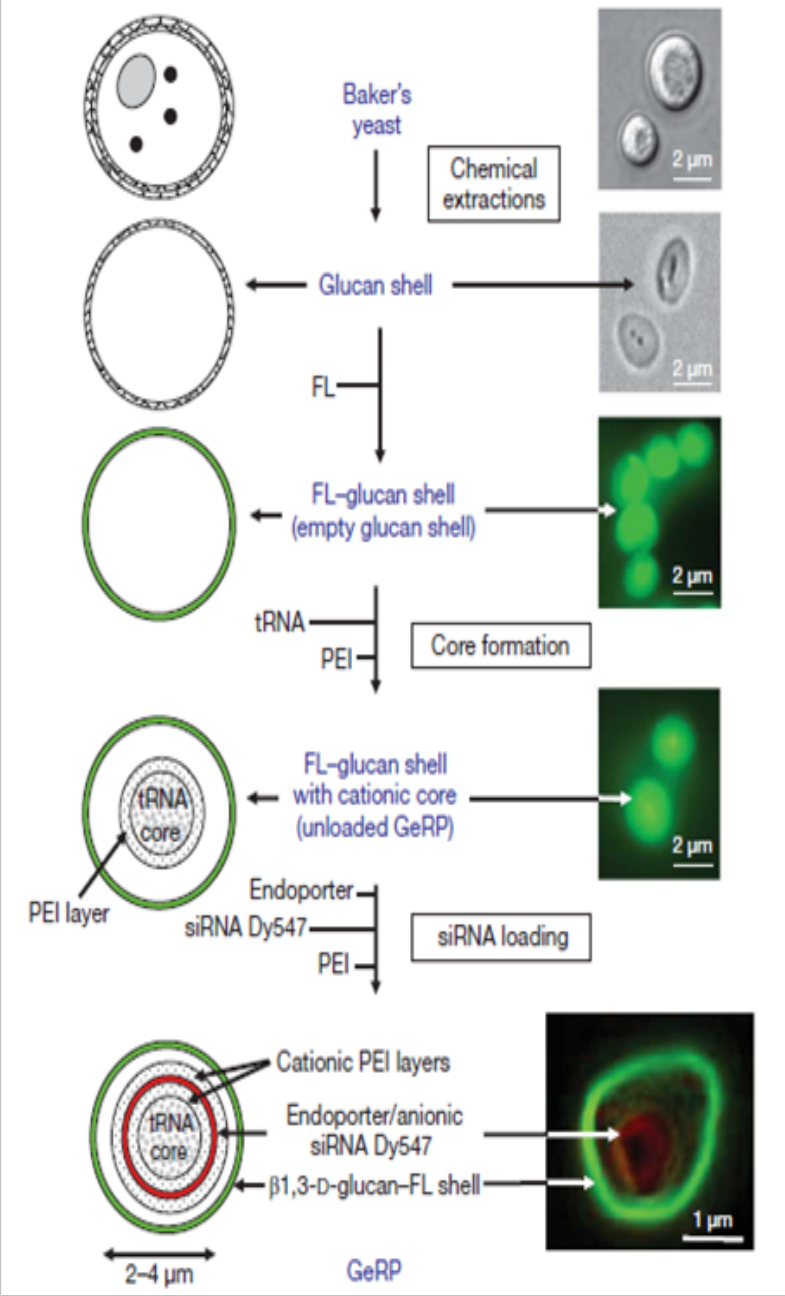

Figure 3 Scheme and results of glucan based effective siRNA preparation. Adapted from ${ }^{12}$ with permission from "Nature Publisher". 
Many other recent targeting strategies/functionalization has been compiled in Table 1 showing different nanostructures involved, different targeting molecules attached, different siRNA targeting

Table I Recent nano-formulations with functionalization genes/proteins and disease addressed to have the idea of possibilities and outcomes in new arena of siRNA or other delivery system.

\begin{tabular}{|c|c|c|c|c|c|c|}
\hline Sn & Nano-carrier & $\begin{array}{l}\text { Targeting/Signaling } \\
\text { functionalization }\end{array}$ & $\begin{array}{l}\text { Target gene } \\
\text { or protein (to } \\
\text { knockdown) }\end{array}$ & $\begin{array}{l}\text { Disease } \\
\text { intervention }\end{array}$ & Comments & References \\
\hline I & $\begin{array}{l}\text { Liposome-- } \\
\text { polycation-- } \\
\text { hyaluronic acid } \\
\text { nanoparticle }\end{array}$ & $\begin{array}{l}\text { single-chain antibody } \\
\text { fragment }\end{array}$ & Myc/MDM2/VEGF & $\begin{array}{l}\text { Lung metastasis } \\
\text { of murine BI6FI0 } \\
\text { melanoma }\end{array}$ & $\begin{array}{l}\text { Down regulated surviving } \\
\text { protein, MAPK pathway }\end{array}$ & 13 \\
\hline 2 & $\begin{array}{l}\text { 6-amino-curdlan } \\
\text { (a polysaccharide } \\
\text { of } D \text {-glucose } \\
\text { bearing } \beta(I \rightarrow 3) \\
\text { linkage ) }\end{array}$ & Nil & $\begin{array}{l}\text { Green fluorescent } \\
\text { protein }\end{array}$ & $\begin{array}{l}\text { Just delivery } \\
\text { demonstration } \\
\text { no disease was } \\
\text { considered }\end{array}$ & $\begin{array}{l}\text { Dectin receptors (in } \\
\text { dendritic cells, monocytes } \\
\text { and B cells) having affinity } \\
\text { for curldan while for } \\
\text { chitosan no receptor } \\
\text { paradigm }\end{array}$ & 14 \\
\hline 3 & $\begin{array}{l}\text { non-covalently } \\
\text { PEGylated } \\
\text { chitosan- } \\
\text { nanoparticles }\end{array}$ & $\begin{array}{l}\text { Naphthyridine- } \\
\text { containing Arg-Gly-Asp } \\
\text { (RGD) tripeptide having } \\
\text { affinity for } \alpha v \beta 3 \text { integrin }\end{array}$ & $\begin{array}{l}\text { Lactate transporter } \\
\text { MCTI and the } \\
\text { glutamine transporter } \\
\text { ASCT2 (key } \\
\text { proteins for energy } \\
\text { transportation) }\end{array}$ & Generalized cancer & $\begin{array}{l}\text { Change in RGD (targeting } \\
\text { functionalization) } \\
\text { characteristic greatly } \\
\text { affect the siRNA delivery } \\
\text { or bioavailability }\end{array}$ & 15 \\
\hline 4 & $\begin{array}{l}\text { Lipid } \\
\text { nanoparticles }\end{array}$ & $\begin{array}{l}\text { Single-chain antibody } \\
\text { (scFv) having specific } \\
\text { affinity for murine } \\
\text { receptor highly } \\
\text { expressed over some } \\
\text { type of dendritic cells }\end{array}$ & $\begin{array}{l}\text { siRNA for silencing } \\
\text { CD } 40, \text { CD80, and } \\
\text { CD86 }\end{array}$ & $\begin{array}{l}\text { Immune responses } \\
\text { or allergy }\end{array}$ & $\begin{array}{l}\text { scFv based targeted } \\
\text { siRNA uptake showed } \\
\text { significant silencing of } \\
\text { genes in comparison to } \\
\text { the non targeted delivery }\end{array}$ & 16 \\
\hline 5 & $\begin{array}{l}\text { Polyion complex } \\
\text { micelle }\end{array}$ & $\begin{array}{l}\text { cyclic RGD peptide } \\
\text { over siRNA }\end{array}$ & $\begin{array}{l}\text { siRNA for silencing } \\
\text { luciferase gene }\end{array}$ & Cervical Cancer & $\begin{array}{l}\text { Disulfide cross-linking } \\
\text { and cholesterol-modified } \\
\text { siRNA for stabilization of } \\
\text { micellar structure }\end{array}$ & 17 \\
\hline 6 & $\begin{array}{l}\text { Lipid } \\
\text { Nanoparticles }\end{array}$ & $\begin{array}{l}\text { Cell penetrating } \\
\text { proteins masked } \\
\text { with near infra red } \\
\text { photon excitation } \\
\text { responsive group } \\
\text { (4,5-dimethoxy-2- } \\
\text { nitrobenzyl) and } \\
\text { Asparagine-Glycine-- } \\
\text { Arginine (NGR) peptide } \\
\text { motif functionalization } \\
\text { over nanoparticles } \\
\text { targeting CDI3 on } \\
\text { tumor cells }\end{array}$ & siRNA against c-myc & Generalized tumor & $\begin{array}{l}\text { Use of near infra red light } \\
\text { to release siRNA instead } \\
\text { of harmful UV light }\end{array}$ & 18 \\
\hline 7 & $\begin{array}{l}\text { Biotinylated } \\
\text { polymeric } \\
\text { micellar } \\
\text { nanocarriers }\end{array}$ & $\begin{array}{l}\text { Streptavidin-conjugated } \\
\text { HER2 antibody } \\
\text { (trastuzumab) }\end{array}$ & $\begin{array}{l}\text { siRNA for silencing } \\
\text { glyceraldehyde-3- } \\
\text { phosphate } \\
\text { dehydrogenase gene }\end{array}$ & $\begin{array}{l}\text { Breast and ovarian } \\
\text { cancer }\end{array}$ & $\begin{array}{l}\text { HER2 receptor is over } \\
\text { expressed in Breast and } \\
\text { ovarian cancer cells. } \\
\text { Endosomes disrupts } \\
\text { as the polymer swells } \\
\text { sensing the acidic } \\
\text { endosomal environment } \\
\text { (Figure 4) }\end{array}$ & 19 \\
\hline 8 & $\begin{array}{l}\text { Lipopeptide } \\
\text { nanoparticles }\end{array}$ & Lipopeptide (Figure 5) & $\begin{array}{l}\text { siRNA silencing Factor } \\
\text { VII (FVII) }\end{array}$ & Liver diseases & $\begin{array}{l}\text { Apoprotein mimicking } \\
\text { lipopeptided enhanced } \\
\text { the penetration ED50 } \\
0.002 \mathrm{mg} / \mathrm{kg}\end{array}$ & 20 \\
\hline 9 & $\begin{array}{l}\text { PEGylated } \\
\text { liposomes }\end{array}$ & $\begin{array}{l}\text { ASI } 4 \text { II, an aptamer } \\
\text { having affinity } \\
\text { for nucleolin } \\
\text { (overexpressed in } \\
\text { cancer cells) }\end{array}$ & $\begin{array}{l}\text { siRNA for silencing } \\
\text { BRAF gene mutated } \\
\text { in } 60 \% \text { cases of } \\
\text { melanomas }\end{array}$ & Melanoma & $\begin{array}{l}\text { Aptamer targeted } \\
\text { delivery of siRNA is a } \\
\text { potential specific therapy }\end{array}$ & 21 \\
\hline
\end{tabular}


Table Continued..

\begin{tabular}{|c|c|c|c|c|c|c|}
\hline Sn & Nano-carrier & $\begin{array}{l}\text { Targeting/Signaling } \\
\text { functionalization }\end{array}$ & $\begin{array}{l}\text { Target gene } \\
\text { or protein (to } \\
\text { knockdown) }\end{array}$ & $\begin{array}{l}\text { Disease } \\
\text { intervention }\end{array}$ & Comments & References \\
\hline 10 & $\begin{array}{l}\text { Graphene oxide } \\
\text { nanosheets } \\
\text { encapsulated } \\
\text { Mesoporous } \\
\text { silicon } \\
\text { nanoparticles }\end{array}$ & $\begin{array}{l}\text { Rabies virus } \\
\text { glycoprotein (RVG) }\end{array}$ & $\begin{array}{l}\text { siRNA silencing } \\
\text { the peptidylprolyl } \\
\text { isomerase B (PPIB) }\end{array}$ & $\begin{array}{l}\text { Neuronal cells in } \\
\text { case of brain injury }\end{array}$ & $\begin{array}{l}\text { The nanosheet delayed } \\
\text { the release of siRNA }\end{array}$ & 22 \\
\hline II & $\begin{array}{l}\text { Chitosan } \\
\text { nanoparticles }\end{array}$ & $\begin{array}{l}\text { Epidermal growth } \\
\text { factor receptor (EGFR) } \\
\text { targeting peptide }\end{array}$ & $\begin{array}{l}\text { Mitotic arrest } \\
\text { deficient- } 2 \text { protein } \\
\text { knockdown }\end{array}$ & $\begin{array}{l}\text { Cisplatin sensitive } \\
\text { and resistant lung } \\
\text { cancer }\end{array}$ & $\begin{array}{l}\text { Synergistic effect of } \\
\text { cisplatin and siRNA } \\
\text { nano-formulation was } \\
\text { observed }\end{array}$ & 23 \\
\hline
\end{tabular}

a
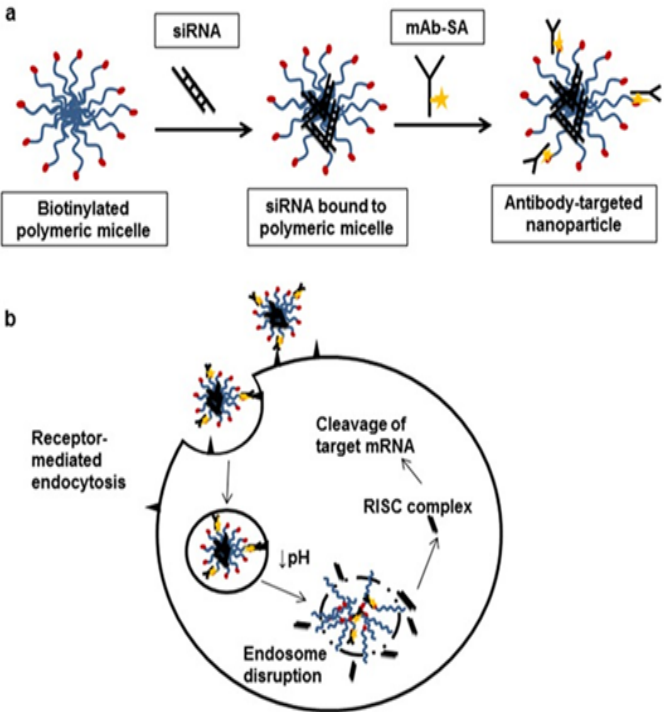

Figure 4 Scheme of preparation and delivery of "polymeric micellar HER-2 antibody attached siRNA" by disruption of endosomes. Adapted from ${ }^{19}$ with "Creative Commons Attribution License".

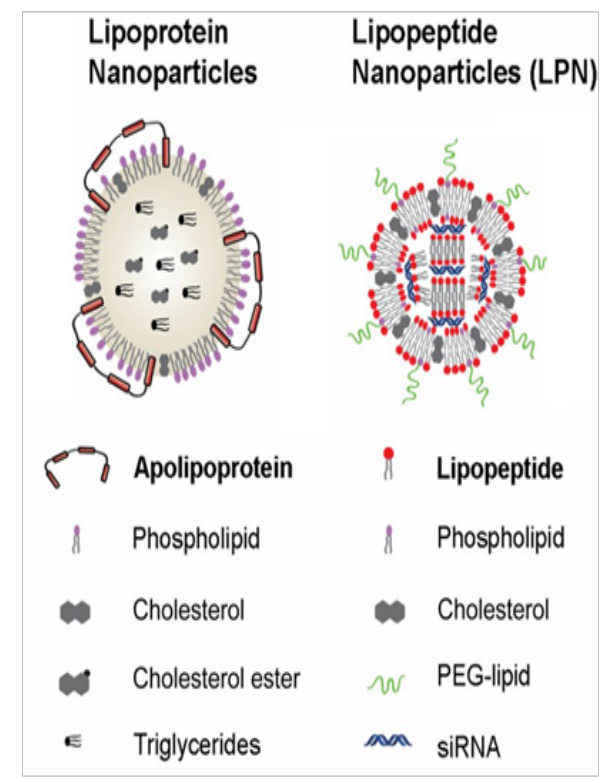

Figure 5 Lipoprotein nanoparticles and lipopeptide nanoparticles. Adapted from $^{20}$ with permission from PNAS publishers.

\section{Conclusion}

A healthy research is going on for the purpose to serve the society suffering from thousands of untreatable diseases. The siRNA delivery is the solution to theoretically all diseases. Bringing thought from test tube to bedside needs attitude, aptitude, imagination, precision so on, all in one direction of siRNA delivery. The strategies applied till now have not covered all the complications of the diseased state. This review aims to show the visions of world class group of scientists and have a thought on your vision or create new vision.

\section{Acknowledgments}

Not applicable.

\section{Conflict of interest}

We authors declare no conflict of interest involved in this article.

\section{References}

1. RNA interference (RNAi).

2. Kanasty R, Dorkin JR, Vegas A, et al. Delivery materials for siRNA therapeutics. Nat Mater. 2013;12(11):967-977.

3. Ganesh S, Iyer AK, Morrissey DV, et al. Hyaluronic acid based selfassembling nanosystems for CD44 target mediated siRNA delivery to solid tumors. Biomaterials. 2013;34(13):3489-3502.

4. Rana TM. Illuminating the silence: understanding the structure and function of small RNAs. Nat Rev Mol Cell Biol. 2007;8(1):23-36.

5. Gavrilov K, Saltzman WM. Therapeutic siRNA: Principles, Challenges, and Strategies. Yale J Biol Med. 2012;85(2):187-200.

6. Bitko V, Musiyenko A, Shulyayeva O, et al. Inhibition of respiratory viruses by nasally administered siRNA. Nat Med. 2005;11(1):50-55.

7. Wang J, Lu Z, Wientjes MG, et al. Delivery of siRNA Therapeutics: Barriers and Carriers. AAPS J. 2010;12(4):492-503.

8. Sandeep Kumar, Asim K Jana, Mithu Maiti, et al. Carbodiimide-mediated immobilization of serratiopeptidase on amino-, carboxyl-functionalized magnetic nanoparticles and characterization for target delivery. Journal of nanoparticle research. 2014;16:2223.

9. Kumar S, Jana AK, Dhamija I, et al. Chitosan-assisted immobilization of serratiopeptidase on magnetic nanoparticles, characterization and its target delivery. J Drug Target. 2014;22(2):123-137.

10. Kumar S, Jana AK, Dhamija I, et al. Preparation, characterization and targeted delivery of serratiopeptidase immobilized on amino-functionalized magnetic nanoparticles. Eur J Pharm Biopharm. 2013;85(3 pt A):413-426. 
11. Alvarez Erviti L, Seow Y, Yin H, et al. Delivery of siRNA to the mouse brain by systemic injection of targeted exosomes. Nat Biotechnol. 2011;29(4):341-345.

12. Aouadi M, Tesz GJ, Nicoloro SM, et al. Orally delivered siRNA targeting macrophage Map4k4 suppresses systemic inflammation. Nature. 2009;458(7242):1180-1184.

13. Chen Y, Zhu X, Zhang X, et al. Nanoparticles modified with tumor-targeting scFv deliver siRNA and miRNA for cancer therapy. Mol Ther. 2010;18(9):1650-1656.

14. Han J, Cai J, Borjihan W, et al. Preparation of novel curdlan nanoparticles for intracellular siRNA delivery. Carbohydr Polym. 2015;117:324330 .

15. Corbet C, Ragelle H, Pourcelle V, et al. Delivery of siRNA targeting tumor metabolism using non-covalent PEGylated chitosan nanoparticles: identification of an optimal combination of ligand structure, linker and grafting method. J Control Release. 2016;223:53-63.

16. Katakowski JA, Mukherjee G, Wilner SE, et al. Delivery of siRNAs to dendritic cells using DEC205-targeted lipid nanoparticles to inhibit immune responses. Mol Ther. 2016;24(1):146-155.

17. Oe Y, Christie RJ, Naito M, et al. Actively-targeted polyion complex micelles stabilized by cholesterol and disulfide cross-linking for systemic delivery of siRNA to solid tumors. Biomaterials. 2014;35(27):78877895 .
18. Yang Y, Yang Y, Xie X, et al. Dual-modified liposomes with a twophoton-sensitive cell penetrating peptide and NGR ligand for siRNA targeting delivery. Biomaterials. 2015;48:84-96.

19. Palanca Wessels MC, Booth GC, Convertine AJ, et al. Antibody targeting facilitates effective intratumoral siRNA nanoparticle delivery to HER2-overexpressing cancer cells. Oncotarget. 2016;7(8):9561-9575.

20. Dong Y, Love KT, Dorkin JR, et al. Lipopeptide nanoparticles for potent and selective siRNA delivery in rodents and nonhuman primates. Proc Natl Acad Sci. 2014;111(11):3955-3960.

21. Li L, Hou J, Liu X, et al. Nucleolin-targeting liposomes guided by aptamer AS1411 for the delivery of siRNA for the treatment of malignant melanomas. Biomaterials. 2014;35(12):3840-3850.

22. Jinmyoung Joo, Ester J Kwon, Jinyoung Kang, et al. Porous silicon graphene oxide core shell nanoparticles for targeted delivery of siRNA to the injured brain. Nanoscale Horiz. 2016;1(5):407-414.

23. Nascimento AV, Singh A, Bousbaa H, et al. Overcoming cisplatin resistance in non-small cell lung cancer with Mad2 silencing siRNA delivered systemically using EGFR-targeted chitosan nanoparticles. Acta Biomater. 2017;47:71-80. 